\title{
Combustion Experiments On A Solid Fuel With Low Sulphur Content
}

\author{
Tudor Prisecaru ${ }^{1}$, Adrian Adam ${ }^{2}$, Lucian Mihăescu ${ }^{1}$, Ionel Pîşă ${ }^{1, *}$, Elena Pop ${ }^{1}$, \\ Malina Prisecaru ${ }^{1}$, Viorel Berbece ${ }^{1}$, Mihai Dragne ${ }^{1}$ \\ ${ }^{1}$ University POLITEHNICA of Bucharest, Romania \\ ${ }^{2}$ ICEMENERG SA, Bucharest, Romania
}

\begin{abstract}
Research was carried out at the experimental installation defined by the $2 \mathrm{MW}$ furnace pilot from the Politehnica University of Bucharest and ICEMENRG institute who was involved for measurements. The purpose of the experimental study is to confirm that the use of a coal with low sulphur content $\mathrm{S}<0.08 \%$ is possible without the use of sulphurpurification installations for industrial purposes. But, the high moisture content of the coal has imposed the problem of its compatibility with a certain milling technology. The pilot plant is equipped with fan mill and pre-drying tower. Under these conditions, this installation allows the grinding of fuels with high moisture content. The experiments focused on the process of ignition, combustion and pollutant emissions, with the exemplification, in particular, of the emission of sulfur dioxide. Also, the outbreak temperatures and the slugging temperature were monitored. For this purpose, the outbreak of the pilot boiler was equipped with all the equipment necessary to follow these parameters. The experiments have shown positive aspects to the burning of this fuel, thus laying the foundations of future tests at industrial installations (first of all, the power plant from Deva is considered).
\end{abstract}

\section{Introduction}

The purpose of the experimental study is to confirm that the use of a coal with low sulphur content $\mathrm{S}<0.08 \%$ is possible without the use of sulphur-purification installations for industrial purposes. The industrial use of this fuel can be implemented after the positive response obtained by the research on the pilot furnace [1]. The energy characteristics of the coal made by ICEMENERG-SA, indicate the following values:

$$
\begin{gathered}
W_{t}^{i}=W_{h}^{i}+W_{i}^{i}=5.31+29.73=35.04 \% ; C^{i}=43.99 \% ; H^{i}=3.22 \% ; \\
A^{i}=2.79 \% ; N^{i}=0.65 \% ; S_{c}^{i}=0.08 \% ; O^{i}=14.23 \%, \\
\text { order } \text { no. } C D 797 / 11.06 .2019 .
\end{gathered}
$$

*Corresponding author: ionel.pisa@upb.ro 
A high humidity, high content, also for oxygen and a very low value for the sulfur in the fuel are noted. The ash is very small. The volatile matter content is high, having the value: $V^{i}=32.42 \%$. The lower heating value is: $Q_{i}^{i}=15,860 \mathrm{~kJ} / \mathrm{kg}$. The fixed carbon, an element of technical analysis has the value:

$$
C_{f}^{i}=100-\left(A^{i}+W_{t}^{i}+V^{i}\right)=29.75 \%
$$

The ignition capacity is defined by the criterion $k_{i}=V^{i} / C_{f}^{i}$, having the value $k_{i}=$ 1.09. This higher than one value indicates a high ignition capacity, allowing a less fine grinding. This is a characteristic of coal with high humidity. From the calculation of combustion (stoichiometric) resulted:

- the theoretical air volume: $V_{a}^{0}=4.24 \mathrm{Nm} 3 / \mathrm{kg}$;

- the theoretical volume of gases: $V_{g}^{0}=4.95 \mathrm{Nm} 3 / \mathrm{kg}$.

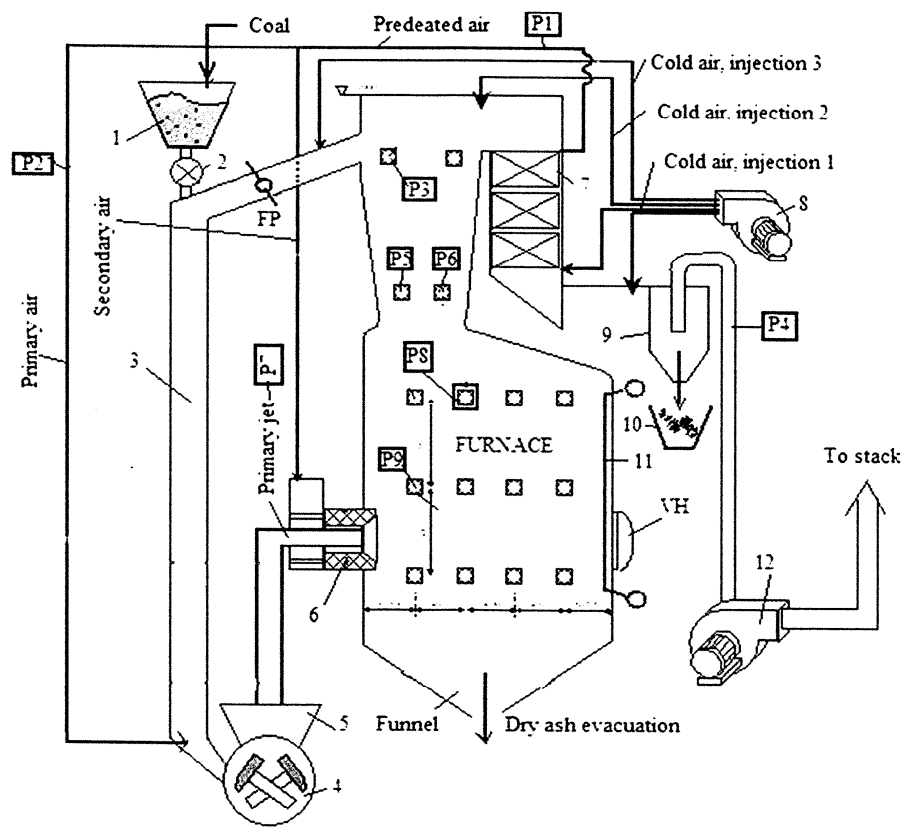

Fig.1 Scheme of $2 \mathrm{MWt}$ installation pilot used to experiments:

1-Raw fuel bunker; 2-Fuel feeder; 3-Pre-drying tower; 4-Mill fan; 5-Dust separator; 6-Straight-flow burner; 7-Tubular air heater; 8-Air fan; 9-Flying ash separator; 10-Ash bunker; 11-Working fluid; 12-Flue gases fan; 13-Flue gases recirculated fan; FP-Flap control; VH-Visit hole; P1, P2, P3.....P9-Measurement points (flow, temperature, pressure).

The experiment carried out on the pilot boiler at UPB (Figure 1) has realized the following elements of similitude with the industrial propose operation expected for this coal [2]:

- milling with fan mill, with a peripheral speed of $85 \mathrm{~m} / \mathrm{s}$. The fineness of the grinding is adjusted by means of an inertial separator. The fan type mill allows a degree of recirculation of the flue gases before the end of the furnace of $r=0.1$. It's an individual pulverization system with direct blowing of pulverized fuel into furnace; 
- the preheating of the combustion air is carried out in the range $250^{\circ} \mathrm{C} \div 300^{\circ} \mathrm{C}$ (in industrial installations the range is between $280^{\circ} \mathrm{C} \div 300^{\circ} \mathrm{C}$ );

- the flow of primary air introduced into the mill can be adjusted according to the volatile matter content of the fuel. Usually, it is a dependence between the proportion of air in the form of primary air and the content of volatile fuel material (ideally, these proportions should be equal);

- the temperature of the flue gases recirculated by the mill is in the temperature range above $840^{\circ} \mathrm{C}$;

- there is thermal support for the sustaining of solid fuel combustion, achieved by combustion of natural gas;

- the thermal loading of the furnace volume is within the limits imposed by the combustion stability.

\section{Experiments Results}

The experiments were performed using a solid fuel consumption $B_{c}$ that varied in the field $(100 \div 120) \mathrm{kg} / \mathrm{h},(0.0277 \div 0.033 \mathrm{~kg} / \mathrm{s})$ and natural gas consumption (as a thermal support) of $B_{g}=16 \mathrm{Nm} 3 / \mathrm{h}(0.0044 \mathrm{Nm} 3 / \mathrm{s})$.

\subsection{The study of grinding}

For the drying of coal, a primary air flow, $V_{a p}=120 \mathrm{Nm} 3 / \mathrm{h}(0.033 \mathrm{Nm} 3 / \mathrm{s})$ at $275^{\circ} \mathrm{C}$ $\div 300^{\circ} \mathrm{C}$ was used and a flow of flue gas recirculated at the end of the furnace $V_{g r}=$ $0.0166 \mathrm{Nm} 3 / \mathrm{s}$ (corresponding to a degree of recirculation of $r=0.1$ ).

The calculation of the drying was performed on the basis of the simplified balance presented in Figure 2. The physical sizes of the thermal balance represent:

$V_{a p}$ - primary air flow, $N m 3 / s, ; c_{a}, c_{g}$-the specific heat of the air and the flue gas, respectively, $N m 3 /(\mathrm{kg} \cdot \mathrm{K}) ; \quad t_{c}, t_{a}, t_{r}, t_{m}-$ the temperature of the fuel, air, recirculated flue gas and flue gas, respectively, ${ }^{\circ} \mathrm{C} ; B_{c}$ - fuel consumption, $\mathrm{kg} / \mathrm{s} ; \Delta \mathrm{W}$ moisture evaporating, $\mathrm{kg}_{\text {water }} / \mathrm{kg}_{\text {fuel }}$ and $c_{c}$ - the specific heat of the fuel, $\mathrm{kJ} /(\mathrm{kg} \cdot \mathrm{K})$.

The following initial values were used in the mathematical model:

$t_{c}=20^{\circ} \mathrm{C}, t_{r}=860^{\circ} \mathrm{C}, t_{m}=62^{\circ} \mathrm{C}, W_{t}{ }^{i}=35.04 \%$.

For evaporation of water, the latent heat of water vaporization has been consumed $(2,500 \mathrm{~kJ} / \mathrm{kg})$. From the calculations resulted the heat introduced into the mill, $Q_{m}=26.47$ $k W$. Unknown size of the thermal balance equation is the quantity of vaporized water in the heel drying process, $\Delta W$. From calculations resulted: $\Delta W=0.282(28.2 \%)$. The moisture of the coal dust at the exit of the mill will be $W^{p}=W_{t}^{i}-\Delta W=35.04-28.2=6.84 \%$.

This value is above the hygroscopic value of the fuel $\left(W_{h}{ }^{i}=5.31 \%\right)$. Under these conditions we have a functioning at the limit of avoiding the danger of explosion [3]. The fineness of the coal dust was determined on a sample taken at the exit of the mill, from the path of the burner mill. The fineness of the grinding is shown in the particle size distribution curve of Figure 3. With $R_{x}$ was noted the total sieve residues for a sieve with the mesh size $x$, expressed in $\mu \mathrm{m}$. The grinding performed a residue on the standard sieve of $90 \mu \mathrm{m}$ by $80 \%$. It results in a semi-rough grinding, but sufficient considering that the volatile content is high, which ensures an easy ignition. The milling coefficient had the value for an adsorbed humidity of $30 \%$. This value indicates the existence of low energy consumption for coal milling. 


\subsection{The study of the combustion process}

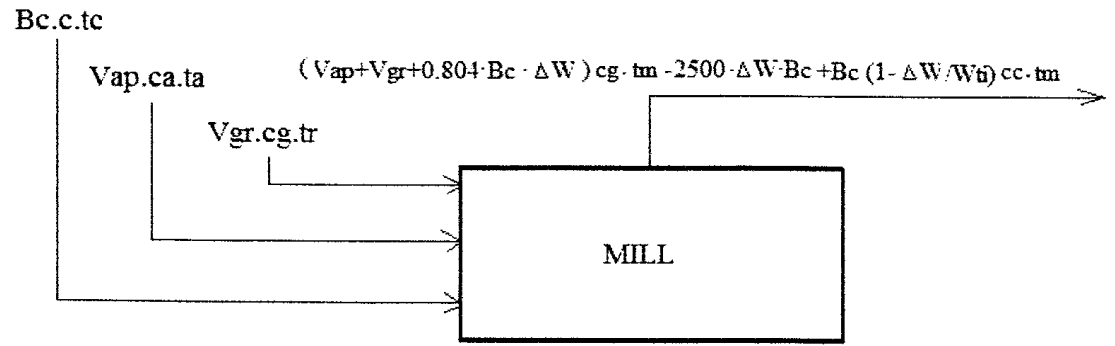

Fig.2 Balance of energy flows from the mill

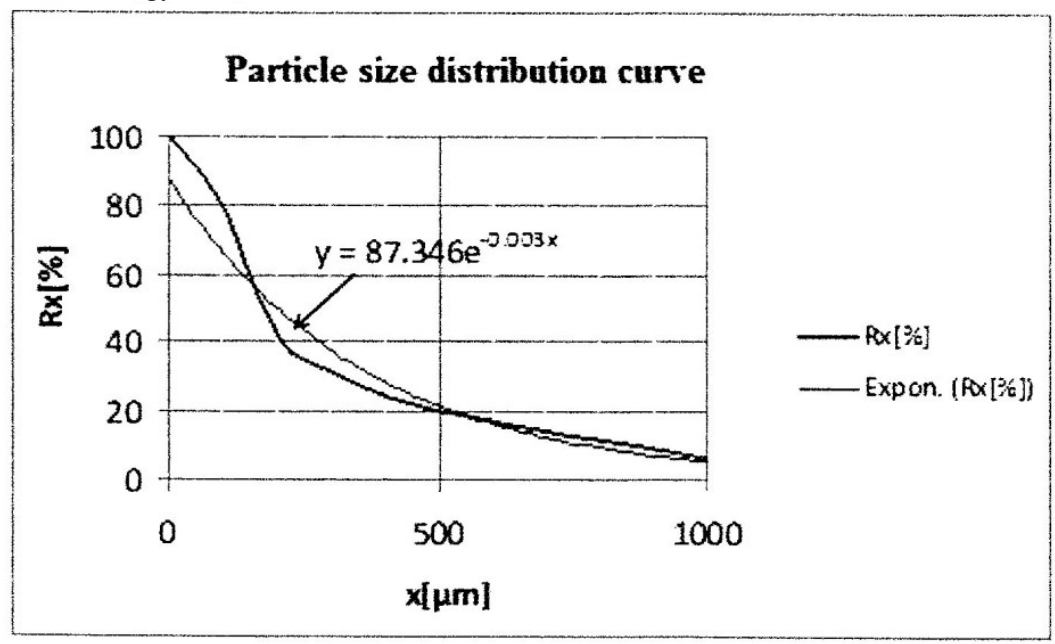

Fig.3 Particle size distribution curve

The combustion conditions in the furnace were carried out by compliance with the global thermal indicators, the main one being the thermal loading of the furnace volume [4]: $\quad q_{v}=P_{t} / V_{f}, k W / \mathrm{m}^{3}$, where $P_{t}$ is thermal power, in $\mathrm{kW}$ and $V_{f}$ is the furnace volume, $m^{3}$. For the solid fuel consumption and of natural gas consumption (as support fuel) the thermal power was: $P_{t}=B_{c} \cdot Q_{i}^{i}+B_{g} \cdot Q_{i}^{u m}, k W$ where $Q_{i}^{i}$ and $Q_{i}^{u m}$ represent the lower heating value of solid fuel and heating value of natural gas, respectively $\left(Q_{i}^{u m}=\right.$ $35,700 \mathrm{~kJ} / \mathrm{Nm} 3)$. Thermal power results:

$P_{t}=620 \mathrm{~kW}$. For a volume of the furnace of $10 \mathrm{~m}^{3}$ resulted a thermal loading of the furnace volume $q_{v}=62 \mathrm{~kW} / \mathrm{m}^{3}$.

The calorific participation of the supporting fuel had the value:

$$
q_{t}=B_{g} \cdot Q_{i}^{u m} / P_{t} \cdot 100=25 \%
$$

The temperature at the end of the furnace had an average value of about $980^{\circ} \mathrm{C}$. Figure 4 shows the technical operating data for the furnace, recorded by the control panel. The through incomplete combustion, determined by measuring the slag and ash unburned had the value $q_{m}=0.55 \%$. This value indicates a properly combustion process, validating the chosen combustion technology. The chemical analysis of the ash resulting from the combustion process indicated:

$\mathrm{SiO}_{2}=22.52 \% ; \mathrm{Fe}_{2} \mathrm{O}_{3}=27.89 \% ; \mathrm{Al}_{2} \mathrm{O}_{3}=7.35 \% ; \mathrm{CaO}=28.74 \% ; \mathrm{MgO}=5.89 \%$ 

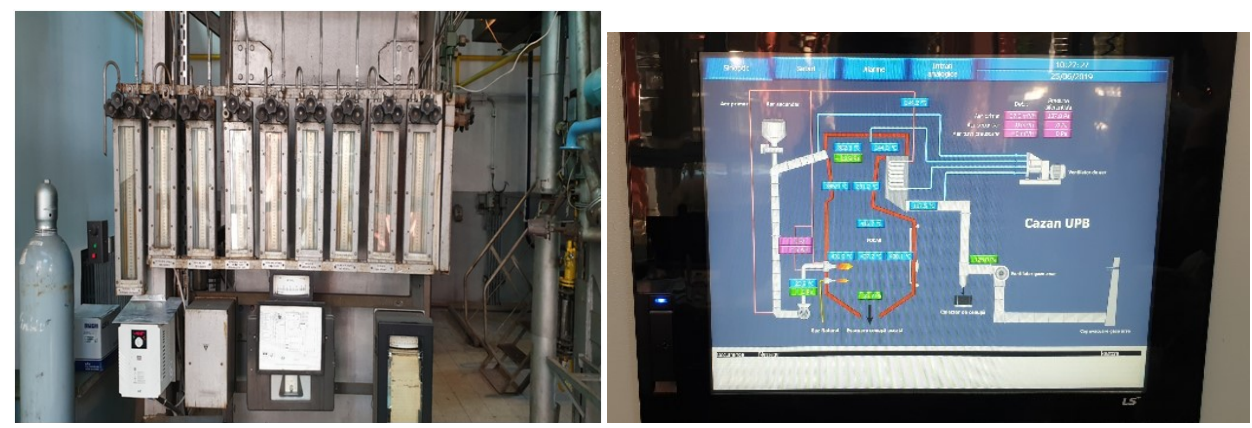

Fig.4 Technical operating data for the furnace

The rest of the elements had been participated under $1 \%$. This ash chemical composition indicates average erosion for the milling elements, because the content of $\mathrm{SiO}_{2}$ it is relatively low. An analysis of the tendency to form adherent slag in the furnace was also imposed. The temperature behavior of the ash depends on its chemical composition, the acid oxides, $\mathrm{SiO}_{2}$ and $\mathrm{Al}_{2} \mathrm{O}_{3}$ having a higher temperature resistance then that of the basic ones as $\mathrm{Fe}_{2} \mathrm{O}_{3}, \mathrm{CaO}, \mathrm{MgO}$. Fusibility index of the ash has the value:

$$
k=\left(\mathrm{SiO}_{2}+\mathrm{Al}_{2} \mathrm{O}_{3}\right) /\left(\mathrm{Fe}_{2}+\mathrm{CaO}+\mathrm{MgO}\right)=0.47
$$

This value indicates a melting temperature of less than $1200{ }^{\circ} \mathrm{C}$. Laboratory tests have shown a softening temperature of over $1000^{\circ} \mathrm{C}$. Further research in this field is required.

\subsection{Emission of $\mathrm{SO}_{2}$}

The numerical applications for an analytical calculation model [5] led to the determination of a $\mathrm{SO}_{2}$ maximum concentration of $205.6 \mathrm{mg} / \mathrm{Nm} 3$. Calculations were performed for the real operating mode of the boiler furnace. This analytically determined size represents a maximum possible value for a given operating regime. In the parallel, experimental measurements were made with a device TESTO 350. The emission was in the field: $\mathrm{SO}_{2}=137 \div 163 \mathrm{mg} / \mathrm{Nm} 3$.

Thus, there is a possible classification in the current pollution norms (200 $\mathrm{mg} / \mathrm{Nm} 3 \mathrm{maxim}$ ), at the industrial operation of the boiler, with this fuel.

\section{Conclusions}

The complex tests performed on the combustion of a solid fuel with low sulfur content on a pilot boiler, demonstrated the possibility of passing the researches on an industrial scale.

This conclusion resulted from:

- classifying the emission of $\mathrm{SO}_{2}$ (the main purpose of the tests) within the accepted environmental limits;

- proper grinding with the help of a fast mill, with a good fineness of dust grinding, a drying accentuated with normal energy consumption;

- obtaining a high temperature field and a low value of through incomplete combustion indicates an efficient combustion of this fuel in the experimental furnace. 
The data determined during the experimental researches are compatible with those for an industrial boiler, the similarity of the two installations constituting, besides, a general objective.

\section{Referances}

1. M. Reznikov, Yu. Lupov, „Steam boilers of thermal power station”, Mir Publishers, Moscow, (1985);

2. ***, European Commission „Integrated Pollution Prevention and Control”, Draft March, (2003);

3. V. Ganapathy „,Steam Generators and Waste Heat Biolers”, CCR Press, 2002, p.493, (2015);

4. L. Mihăescu, G. Negreanu, M. Ceclan, I. Oprea, I. Pîşă, M. Prisecaru, M. Georgescu, E. Pop, V. Berbece, ,,Sisteme şi echipamente termice pentru producerea de energie” Ed. Printech, ISBN 978-606-521-872-7, Bucureşti (2012), (in Romanian);

5. I. Pîșă, ,Generatoare de abur. Calculul instalațiilor anexe”, Ed. Politehnica Press, ISBN 978-606-515-836-8, București (2018), (in Romanian). 